\title{
A Survey of the Regulatory Requirements for BCS-Based Biowaivers for Solid Oral Dosage Forms by Participating Regulators and Organisations of the International Generic Drug Regulators Programme
}

Joy van Oudtshoorn ${ }^{1}$, Alfredo García-Arieta ${ }^{2}$, Gustavo Mendes Lima Santos ${ }^{3}$, Christopher Crane ${ }^{4}$, Clare Rodrigues ${ }^{5}$, Craig Simon ${ }^{6}$, Ji Myoung Kim ${ }^{7}$, Sang Aeh Park ${ }^{7}$, Yusuke Okada ${ }^{8}$, Ryosuke Kuribayashi ${ }^{8}$, Chantal Pfäffli ${ }^{9}$, Arno Nolting9, Iván Omar Calderón Lojero ${ }^{10}$, Zulema Rodríguez Martínez ${ }^{10}$, Wen-Yi Hung ${ }^{11}$, April C. Braddy ${ }^{12}$, Nancy Arciniegas Leal $^{13}$, Diego Gutierrez Triana ${ }^{13}$, Mitch Clarke ${ }^{14}$, Peter Bachmann ${ }^{15}$

${ }^{1}$ Medicines Control Council, Pretoria, South Africa; ${ }^{2}$ World Health Organisation Prequalification of Medicines Programme and Agencia Española de Medicamentos y Productos Sanitarios, Madrid, Spain; ${ }^{3}$ Agência Nacional de Vigilância Sanitária, Brasília, Brazil; ${ }^{4}$ Therapeutic Goods Administration, Woden, Australia; ${ }^{5}$ Health Sciences Authority Health Products Regulation Group, Pre-Market Cluster, Singapore; ${ }^{6}$ Health Canada, Ottawa, Ontario, Canada; ${ }^{7}$ Ministry of Food and Drug Safety, Chungcheongbuk-do, South Korea; ${ }^{8}$ Pharmaceuticals and Medical Devices Agency, Tokyo, Japan; ${ }^{9}$ Swissmedic, Bern, Switzerland; ${ }^{10}$ Comisión Federal para la Protección contra Riesgos Sanitarios, Oklahoma, Ciudad de México, México; ${ }^{11}$ Taiwan Food and Drug Administration, Taipei, Taiwan, R.O.C.; ${ }^{12}$ United States Department of Health and Human Services, Food and Drug Administration, Center for Drug Evaluation and Research, Office of Generic Drugs, Silver Spring, MD, USA; ${ }^{13}$ Instituto Nacional de Vigilancia de Medicamentos y Alimentos, Bogotá. Colombia; ${ }^{14} \mathrm{New}$ Zealand Medicines and Medical Devices Safety Authority, Ministry of Health, Wellington, New Zealand; ${ }^{15} \mathrm{CMDh}$ at European Medicines Agency and Federal Institute for Drugs and Medical Devices, Bonn, Germany.

Received December 15, 2017; Revised, January 22, 2018; Accepted, January 23, 2018; Published, January 25, 2018.

\begin{abstract}
Purpose: The Biopharmaceutics Classification System (BCS) based biowaiver is a scientific model which enables the substitution of in vivo bioequivalence studies with in vitro data as evidence of therapeutic equivalence subject to certain conditions. Despite being based on the same principles, BCS-based biowaivers are interpreted and regulated differently among international regulatory agencies. In this survey, the Bioequivalence Working Group (BEWG) of the International Generic Drug Regulators Programme (IGDRP) compared the criteria for BCS-based biowaivers applied by the participating regulators and organisations. Methods: Differences and similarities regarding solubility, permeability, dissolution, excipients and fixed-dose combination products, were identified and compared in a detailed survey of each participant's criteria for BCS-based biowaivers. These criteria were determined based upon the participants' respective regulatory guidance documents, policies and practices. Results: This review has, with the exception of two participants who do not accept BCS-based biowaivers, revealed that most IGDRP participants interpret the BCS principles and conditions similarly but notable differences exist in the application of these principles. Conclusion: Although many similarities exist, this review identifies several opportunities for greater convergence of regulatory requirements amongst the surveyed jurisdictions.
\end{abstract}

This article is open to POST-PUBLICATION REVIEW. Registered readers (see "For Readers") may comment by clicking on ABSTRACT on the issue's contents page.

\section{INTRODUCTION}

The International Generic Drug Regulators Programme (IGDRP) was created to promote collaboration and convergence in generic drug regulatory programmes in order to address the challenges posed by increasing workloads, globalisation and complexity of scientific issues (1). The IGDRP has two technical working groups, the Quality Working Group (QWG) and the Bioequivalence Working Group (BEWG) that focus on the regulation of quality and bioequivalence aspects respectively, for generic drugs.

The BEWG aims to promote greater collaboration, regulatory convergence and potential mutual reliance on bioequivalence assessments. This group is composed of the following regulators/agencies: Agência Nacional de Vigilância Sanitária (ANVISA, Brazil), Federal

Corresponding Author: Joy van Oudtshoorn, Medicines Control Council, 33 Kalkoen Street, Monument Park X, Pretoria 0181 South Africa; Email: Joyvo@icon.co.za 
Commission for the Protection against Sanitary Risks (COFEPRIS, Mexico), European Medicines Agency (EMA, EU), Health Canada (HC), the Health Sciences Authority (HSA, Singapore), Instituto Nacional de Vigilancia de Medicamentos y Alimentos (INVIMA, Colombia), the Medicines Control Council (MCC, South Africa), Medsafe (New Zealand), the Ministry of Food and Drug Safety (MFDS, South Korea), the Pharmaceuticals and Medical Devices Agency (PMDA, Japan), Swissmedic (Switzerland), the Taiwan Food and Drug Administration (TFDA), Therapeutic Goods Administration (TGA, Australia), as well as observers from the World Health Organisation (WHO), and the United States Food and Drug Administration (USFDA).

The Biopharmaceutics Classification System (BCS) based biowaiver is a scientific model for evaluating therapeutic equivalence of products where the intention is to substitute in vivo bioequivalence studies as evidence of therapeutic equivalence of generic drug products with comparative in vitro studies. The application of this approach is based on the characteristics of drug absorption or permeability and solubility, as well as drug dissolution and the nature of the excipients used in the formulation (2,3). As oral drug absorption is controlled by the permeability of the drug substance through the gastrointestinal tract membrane and the solubility/dissolution of the drug dose in the gastrointestinal milieu (3), the rate and extent of absorption would be the same if the gastrointestinal concentration-time profile of the same drug substance under all luminal conditions were the same and if the excipients did not affect the absorption/permeability process. Despite being based on this single principle, BCS-based biowaivers are interpreted and regulated differently among international regulatory agencies (4).

The objective of this paper is to describe the current BCS-based biowaiver regulatory requirements of the regulators/agencies that participate actively in the IGDRP BEWG, and to identify the commonalities and differences among these organisations. This will enable agencies to consider convergence when the opportunities to do so arise.

\section{MATERIALS AND METHODS}

The IGDRP BEWG conducted a detailed survey of the criteria for BCS-based biowaivers applied by the participating regulators and organisations according to their respective regulatory guidance documents and policies (5-19).

\section{RESULTS}

\section{General aspects}

BCS Class I (highly soluble drug substance with high permeability) biowaivers are allowed by all of the listed participants except Japan and Mexico. These two participants are therefore not included in the following statements except where otherwise indicated.

BCS Class III (highly soluble drug substance with low permeability) biowaivers are currently not accepted by Brazil, Japan, Mexico, Singapore, South Korea and the US. The remainder of the participants accept waivers for products containing BCS class III drug substances, but have stricter conditions than for products containing BCS Class I drug substances. It is noted that the US is currently assessing the possibility of accepting BCS Class III biowaivers (20).

BCS Class II (low solubility drug substance with high permeability) biowaivers and BCS Class IV (low solubility drug substance with low permeability) biowaivers are not accepted by any of the participating regulatory agencies and organisations.

No participant accepts BCS-based biowaivers for products containing narrow therapeutic index drugs (NTIDs) (also known as narrow therapeutic range (NTR) drugs or critical dose drugs (CDDs)). The definition or classification of NTIs is not harmonized and a case by case approach is generally applied by participants. When submitting an application for a BCS-based biowaiver, applicants should always confirm that the product does not contain an NTID or CDD and provide a supporting justification.

All participants agree that BCS-based biowaivers are limited to oral immediate release products containing systemically acting drugs; none would accept BCS-based biowaivers for modified release products. Australia, New Zealand and South Africa may accept BCS-based biowaivers where the generic and reference products are different oral dosage forms such as capsules and tablets.

Provided both the salts belong to BCS Class I, BCS-based biowaivers for products containing different salts of the drug would be accepted by Australia, EU, New Zealand, Singapore, South Africa and Switzerland. However, BCS-based biowaivers for different esters, ethers, isomers, 
mixtures of isomers, complexes or derivatives of the drug, would not be accepted by any participant as these differences could lead to differences in bioavailability that would not be detectable using the BCS-based biowaiver criteria $(5,15)$.

As the oral cavity absorption mechanisms differ from the gastrointestinal characteristics applicable for the BCS, BCS-based biowaivers for orodispersible tablets would not be accepted by the US, while they would be considered by the rest of the members including the $\mathrm{WHO}$, provided that the drug substance has no buccal or sublingual absorption. An additional labelling requirement that the product is to be taken with water is required by Australia, Canada, EU, Switzerland and Taiwan as the BCS solubility criterion described below is based on the concomitant intake of a glass of water (approximately $250 \mathrm{~mL}$ ). However, only the Canadian guideline stipulates this requirement.
The US is currently considering granting a waiver for oral disintegrating tablets only if absorption from the oral cavity is ruled out (20).

BCS Biowaivers for oral suspensions may be accepted by Australia, Brazil, EU, New Zealand, Singapore, South Africa and Switzerland. In addition, according to the product-specific recommendation of the USFDA, a BCS-based biowaiver could also be considered for a linezolid suspension (21).

With the exception of Brazil and Taiwan, all participants require BCS-based biowaiver data for each strength of the generic and the corresponding strength of the reference product. Brazil and Taiwan require that BCS-based biowaiver data be provided for the highest strength together with the usual additional strength biowaiver data for the other non-studied strengths of the generic product.

Table 1. Comparison of General Aspects of Biowaiver Requirements of IGDRP Participants (Y: Yes; N: No) ${ }^{\mathrm{a}}$

\begin{tabular}{|c|c|c|c|c|c|c|c|c|c|c|c|c|c|c|}
\hline General aspects & 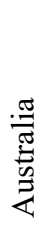 & 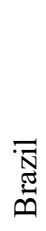 & 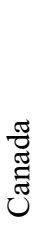 & $\frac{\frac{\pi}{0}}{\frac{0}{0}}$ & 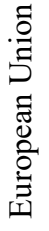 & 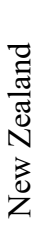 & 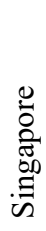 & 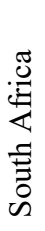 & 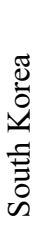 & 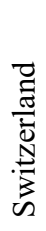 & . & $\mathscr{D}$ & $\stackrel{0}{3}$ & \\
\hline BCS I & Y & Y & $\mathrm{Y}$ & Y & $\mathrm{Y}$ & $\mathrm{Y}$ & Y & $\mathrm{Y}$ & Y & $\mathrm{Y}$ & Y & Y & & $\mathrm{Y}$ \\
\hline BCS II & $\mathrm{N}$ & $\mathrm{N}$ & $\mathrm{N}$ & $\mathrm{N}$ & $\mathrm{N}$ & $\mathrm{N}$ & $\mathrm{N}$ & $\mathrm{N}$ & $\mathrm{N}$ & $\mathrm{N}$ & $\mathrm{N}$ & $\mathrm{N}$ & & $\mathrm{N}$ \\
\hline BCS III & $\mathrm{Y}$ & $\mathrm{N}$ & $\mathrm{Y}$ & $\mathrm{Y}$ & $\mathrm{Y}$ & $\mathrm{Y}$ & $\mathrm{N}$ & $\mathrm{Y}$ & $\mathrm{N}$ & $\mathrm{Y}$ & $\mathrm{Y}$ & $\mathrm{N}^{\mathrm{b}}$ & & $\mathrm{Y}$ \\
\hline BCS IV & $\mathrm{N}$ & $\mathrm{N}$ & $\mathrm{N}$ & $\mathrm{N}$ & $\mathrm{N}$ & $\mathrm{N}$ & $\mathrm{N}$ & $\mathrm{N}$ & $\mathrm{N}$ & $\mathrm{N}$ & $\mathrm{N}$ & $\mathrm{N}$ & & $\mathrm{N}$ \\
\hline NTID / CDD not allowed & $\mathrm{Y}$ & $\mathrm{Y}$ & $\mathrm{Y}$ & $\mathrm{Y}$ & $\mathrm{Y}$ & $\mathrm{Y}$ & $\mathrm{Y}$ & $\mathrm{Y}$ & $\mathrm{Y}$ & $\mathrm{Y}$ & $\mathrm{Y}$ & $\mathrm{Y}$ & & $\mathrm{Y}$ \\
\hline \multicolumn{15}{|l|}{ Dosage form } \\
\hline Oral solid IR & $\mathrm{Y}$ & $\mathrm{Y}$ & $\mathrm{Y}$ & $\mathrm{Y}$ & $\mathrm{Y}$ & $\mathrm{Y}$ & $\mathrm{Y}$ & $\mathrm{Y}$ & $\mathrm{Y}$ & $\mathrm{Y}$ & $\mathrm{Y}$ & Y & & Y \\
\hline $\begin{array}{l}\text { Capsules and tablets } \\
\text { similar }\end{array}$ & $\mathrm{Y}$ & $\mathrm{N}$ & $\mathrm{N}$ & $\mathrm{N}$ & $\mathrm{N}$ & $\mathrm{Y}$ & $\mathrm{N}$ & $\mathrm{Y}$ & $\mathrm{N}$ & $\mathrm{N}$ & $\mathrm{N}$ & $\mathrm{N}$ & & $\mathrm{N}$ \\
\hline Modified release & $\mathrm{N}$ & $\mathrm{N}$ & $\mathrm{N}$ & $\mathrm{N}$ & $\mathrm{N}$ & $\mathrm{N}$ & $\mathrm{N}$ & $\mathrm{N}$ & $\mathrm{N}$ & $\mathrm{N}$ & $\mathrm{N}$ & $\mathrm{N}$ & & $\mathrm{N}$ \\
\hline $\begin{array}{l}\text { Orodispersible tablets, if } \\
\text { justified }\end{array}$ & $\mathrm{Y}$ & $\mathrm{Y}$ & $\mathrm{Y}$ & $\mathrm{Y}$ & $\mathrm{Y}$ & $\mathrm{Y}$ & $\mathrm{Y}$ & $\mathrm{Y}$ & $\mathrm{Y}$ & $\mathrm{Y}$ & $\mathrm{Y}$ & $\mathrm{N}$ & & $\mathrm{Y}$ \\
\hline Oral suspensions & $\mathrm{Y}$ & Y & $\mathrm{N}$ & $\mathrm{N}$ & Y & $\mathrm{Y}$ & Y & $\mathrm{Y}$ & $\mathrm{N}$ & $\mathrm{Y}$ & $\mathrm{N}$ & $\mathrm{N}^{\mathrm{c}}$ & & \\
\hline $\begin{array}{l}\text { Additional strengths within } \\
\text { dose range, not marketed by } \\
\text { innovator }\end{array}$ & $\mathrm{Y}$ & $\mathrm{N}$ & $\mathrm{N}$ & $\mathrm{Y}$ & $\mathrm{Y}$ & $Y$ & $\mathrm{Y}$ & $\mathrm{Y}$ & $\mathrm{N}$ & $\mathrm{Y}$ & $\mathrm{Y}$ & $\mathrm{N}$ & & $\mathrm{Y}$ \\
\hline $\begin{array}{l}\text { Data for each product } \\
\text { strength vs corresponding } \\
\text { reference strength }\end{array}$ & $\mathrm{Y}$ & $\mathrm{N}$ & $\mathrm{Y}$ & $\mathrm{Y}$ & $\mathrm{Y}$ & $\mathrm{Y}$ & $\mathrm{Y}$ & $\mathrm{Y}$ & $\mathrm{Y}$ & $\mathrm{Y}$ & $\mathrm{N}$ & $\mathrm{Y}$ & & $\mathrm{Y}$ \\
\hline $\begin{array}{l}\text { Different salts if test and } \\
\text { reference are both BCS } \\
\text { Class I }\end{array}$ & $\mathrm{Y}$ & $\mathrm{N}$ & $\mathrm{N}$ & $\mathrm{N}$ & $\mathrm{Y}$ & $\mathrm{Y}$ & $\mathrm{Y}$ & $\mathrm{Y}$ & $\mathrm{N}$ & $\mathrm{Y}$ & $\mathrm{N}$ & $\mathrm{N}$ & & $\mathrm{N}$ \\
\hline $\begin{array}{l}\text { Different esters, ethers, } \\
\text { isomers, mixtures of } \\
\text { isomers, complexes or } \\
\text { derivatives }\end{array}$ & $\mathrm{N}$ & $\mathrm{N}$ & $\mathrm{N}$ & $\mathrm{N}$ & $\mathrm{N}$ & $\mathrm{N}$ & $\mathrm{N}$ & $\mathrm{N}$ & $\mathrm{N}$ & $\mathrm{N}$ & $\mathrm{N}$ & $\mathrm{N}$ & & $\mathrm{N}$ \\
\hline
\end{tabular}


Table 1. Continued...

a Japan and Mexico are not mentioned in this table as they do not currently accept BCS-based biowaivers.

${ }^{b}$ Currently under consideration for acceptance by the US.

${ }^{\mathrm{c}}$ May be acceptable on a case-by-case basis.

\section{Solubility of the drug substance}

All participants require that the solubility of the drug substance be determined at the maximum approved single therapeutic dose, except South Korea, Taiwan and the US, who require the solubility to be determined at the highest strength of the reference product.

The conditions used when determining the solubility of the drug substance include the $\mathrm{pH}$ range and temperature of the medium. The solubility of the drug substance must generally be investigated in aqueous buffer solutions in the $\mathrm{pH}$ range 1 to 6.8 , with the exception of South Korea and the US, where a higher upper $\mathrm{pH}$ of 7.5 is required, and Canada, Colombia, South Africa and the WHO, who require the $\mathrm{pH}$ of 1.2 as opposed to 1. South Korea and the US are however reviewing their current upper limit and also considering $\mathrm{pH}$ $6.8(20)$.

The drug substance solubility must generally be investigated at least at three pHs, namely $\mathrm{pH}$ 1.2, 4.5 and 6.8. Brazil, Canada, Colombia and the WHO require the solubility of the drug substance to be determined at these $\mathrm{pHs}$ independent of the pKa of the drug substance. Canada, Colombia and the $\mathrm{WHO}$ have no requirement regarding $\mathrm{pKa}$. The EU, Australia, New Zealand, Singapore, Switzerland and Taiwan require solubility determinations at additional $\mathrm{pHs}$ if the drug substance solubility fluctuates with $\mathrm{pH}$ and also require the $\mathrm{pKa}$ to be taken into account if it is in the physiological range. South Korea and the US similarly require three to five $\mathrm{pHs}$ if the $\mathrm{pKa}$ is between 3 and 5. Most participants additionally require estimation of the concentration at saturation, with the exception of Brazil, Colombia, Singapore, South Africa and Taiwan who require that only the highest strength or dose is dissolved in $250 \mathrm{~mL}$ of the corresponding buffers. Canada, South Korea and the US specifically require the calculation of the dose solubility volume (DSV).To ensure that the solubility at a specific $\mathrm{pH}$ is not influenced by a change in the $\mathrm{pH}$ during solubility testing, all participants require verification of the $\mathrm{pH}$ after the drug substance solubility study. The solubility should generally also be determined in triplicate, although Australia, the EU, New Zealand, Singapore, South Africa and Switzerland would accept two duplicate measurements. The shake-flask method is the generally accepted method for determining solubility; alternatively, any other method, e.g. acid or base titration methods, would be considered if justified. Lastly, all participants require the solubility to be determined at $37^{\circ} \mathrm{C}$.

Literature references indicating the drug substance solubility would be considered by Australia, Brazil, EU, New Zealand, Singapore, South Africa, Switzerland, and the WHO, but not by Canada, Colombia, South Korea, Taiwan and the US. However, as one is unlikely to find all the required data in the literature, applicants are generally expected to submit the experimental solubility data obtained with the drug substance employed in the manufacture of the proposed product.

\section{Permeability of the drug substance}

Complete absorption is generally related to high permeability. The permeability classification is based indirectly on the fraction of the dose absorbed, not the systemic bioavailability, and/or directly on measurements of the rate of mass transfer across the human intestinal membrane (2).

All participants require that the drug substance absorption must be at least $85 \%$ for classification as highly permeable in humans, except South Korea and the US who require $90 \%$. South Korea and the US are however reviewing this and also considering the lower limit of at least $85 \%$.

All participants accept the drug substance permeability/absorption characteristics stated in the approved reference product labelling. Participants other than the US would also consider literature data as evidence of high permeability/absorption. Colombia additionally specifies that literature data are accepted only if it can clearly be established that the data were derived from appropriately designed studies. 
Table 2. Comparison of Drug Substance Solubility Determination Requirements of IGDRP Participants (Y: Yes; $\mathrm{N}: \mathrm{No})^{\mathrm{a}}$

\begin{tabular}{|c|c|c|c|c|c|c|c|c|c|c|c|c|c|c|}
\hline Drug Substance Solubility & 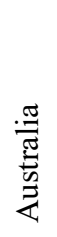 & : & 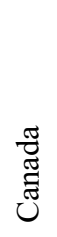 & $\frac{\frac{\pi}{0}}{\frac{\tilde{E}}{0}}$ & 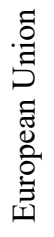 & 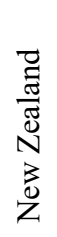 & 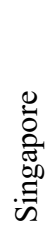 & 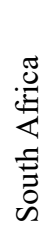 & 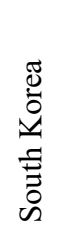 & 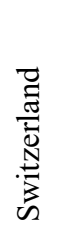 & 胥 & $\stackrel{\Omega}{D}$ & $\stackrel{0}{3}$ & \\
\hline \multicolumn{15}{|l|}{$\begin{array}{l}\text { Quantity of drug substance } \\
\text { equal to }\end{array}$} \\
\hline Highest strength product & $\mathrm{N}$ & $\mathrm{N}$ & $\mathrm{N}$ & $\mathrm{N}$ & $\mathrm{N}$ & $\mathrm{N}$ & $\mathrm{N}$ & $\mathrm{N}$ & $\mathrm{Y}$ & $\mathrm{N}$ & $\mathrm{Y}$ & $\mathrm{Y}$ & & $\mathrm{N}$ \\
\hline Maximum dose & Y & $\mathrm{Y}$ & Y & Y & Y & Y & $\mathrm{Y}$ & $\mathrm{Y}$ & $\mathrm{N}$ & $\mathrm{Y}$ & $\mathrm{N}$ & $\mathrm{N}$ & & $\mathrm{Y}$ \\
\hline Volume $250 \mathrm{~mL}$ & $\mathrm{Y}$ & $\mathrm{Y}$ & $\mathrm{Y}$ & $\mathrm{Y}$ & $\mathrm{Y}$ & $\mathrm{Y}$ & $\mathrm{Y}$ & $\mathrm{Y}$ & $\mathrm{Y}$ & $\mathrm{Y}$ & $\mathrm{Y}$ & $\mathrm{Y}$ & & $\mathrm{Y}$ \\
\hline $\mathrm{pH}$ range 1 to 7.5 & $\mathrm{~N}$ & $\mathrm{~N}$ & $\mathrm{~N}$ & $\mathrm{~N}$ & $\mathrm{~N}$ & $\mathrm{~N}$ & $\mathrm{~N}$ & $\mathrm{~N}$ & $\mathrm{Y}$ & $\mathrm{N}$ & $\mathrm{N}$ & $\mathrm{Y}$ & & $\mathrm{N}$ \\
\hline $\mathrm{pH}$ range 1 to 6.8 & $\mathrm{Y}$ & $\mathrm{N}$ & $\mathrm{N}$ & $\mathrm{N}$ & $\mathrm{Y}$ & $\mathrm{Y}$ & $\mathrm{Y}$ & $\mathrm{N}$ & $\mathrm{N}^{\mathrm{b}}$ & $\mathrm{Y}$ & $\mathrm{Y}$ & $\mathrm{N}^{\mathrm{b}}$ & & $\mathrm{N}$ \\
\hline $\mathrm{pH}$ range 1.2 to 6.8 & $\mathrm{~N}$ & $\mathrm{Y}$ & $\mathrm{Y}$ & $\mathrm{Y}$ & $\mathrm{N}$ & $\mathrm{N}$ & $\mathrm{N}$ & $\mathrm{Y}$ & $\mathrm{N}$ & $\mathrm{N}$ & $\mathrm{N}$ & $\mathrm{N}$ & & $\mathrm{Y}$ \\
\hline \multicolumn{15}{|l|}{$3 \mathrm{pHs} 1.2,4.5,6.8$} \\
\hline $\mathrm{pKa}$ independent & $\mathrm{N}$ & $\mathrm{Y}$ & $\mathrm{Y}$ & $\mathrm{Y}$ & $\mathrm{N}$ & $\mathrm{N}$ & $\mathrm{N}$ & $\mathrm{N}$ & $\mathrm{N}$ & $\mathrm{N}$ & $\mathrm{N}$ & $\mathrm{N}$ & & $\mathrm{Y}$ \\
\hline $\mathrm{pKa}$ dependent requirements & Y & $\mathrm{N}$ & $\mathrm{N}$ & $\mathrm{N}$ & $\mathrm{Y}$ & $\mathrm{Y}$ & $\mathrm{Y}$ & $\mathrm{N}$ & $\mathrm{Y}$ & $\mathrm{Y}$ & $\mathrm{Y}$ & $\mathrm{Y}$ & & $\mathrm{N}$ \\
\hline $\begin{array}{l}3 \text { to } 5 \mathrm{pHs} \text { if } \mathrm{pKa} \text { in } \\
\text { range } 3-5\end{array}$ & $\mathrm{~N}$ & $\mathrm{~N}$ & $\mathrm{~N}$ & $\mathrm{~N}$ & $\mathrm{~N}$ & $\mathrm{~N}$ & $\mathrm{~N}$ & $\mathrm{~N}$ & Y & $\mathrm{N}$ & $\mathrm{N}$ & Y & & $\mathrm{N}$ \\
\hline $\begin{array}{l}\text { Estimation of concentration at } \\
\text { saturation }\end{array}$ & $\mathrm{Y}$ & $\mathrm{N}$ & $\mathrm{Y}$ & $\mathrm{N}$ & $\mathrm{Y}$ & $\mathrm{Y}$ & $\mathrm{N}$ & $\mathrm{N}$ & $\mathrm{Y}$ & $\mathrm{Y}$ & $\mathrm{N}$ & $\mathrm{Y}$ & & $\mathrm{Y}$ \\
\hline $\begin{array}{l}\text { Verification of } \mathrm{pH} \\
\text { after solubility study }\end{array}$ & $\mathrm{Y}$ & $\mathrm{Y}$ & $\mathrm{Y}$ & $\mathrm{Y}$ & $\mathrm{Y}$ & $\mathrm{Y}$ & $\mathrm{Y}$ & $\mathrm{Y}$ & $\mathrm{Y}$ & $\mathrm{Y}$ & $\mathrm{Y}$ & $\mathrm{Y}$ & & $\mathrm{Y}$ \\
\hline Triplicate & $\mathrm{Y}$ & $\mathrm{Y}$ & $\mathrm{Y}$ & $\mathrm{Y}$ & $\mathrm{Y}$ & $\mathrm{Y}$ & $\mathrm{Y}$ & $\mathrm{Y}$ & $\mathrm{Y}$ & $\mathrm{Y}$ & $\mathrm{Y}$ & $\mathrm{Y}$ & & $\mathrm{Y}$ \\
\hline Duplicate determination & $\mathrm{Y}$ & $\mathrm{N}$ & $\mathrm{N}$ & $\mathrm{N}$ & Y & $\mathrm{Y}$ & $\mathrm{Y}$ & $\mathrm{Y}$ & $\mathrm{N}$ & $\mathrm{Y}$ & $\mathrm{N}$ & $\mathrm{N}$ & & $\mathrm{N}$ \\
\hline $\begin{array}{l}\text { Shake flask or } \\
\text { other method if justified }\end{array}$ & $\mathrm{Y}$ & $\mathrm{Y}$ & $\mathrm{Y}$ & $\mathrm{Y}$ & $\mathrm{Y}$ & $\mathrm{Y}$ & $\mathrm{Y}$ & $\mathrm{Y}$ & $\mathrm{Y}$ & $\mathrm{Y}$ & $\mathrm{Y}$ & $\mathrm{Y}$ & & $\mathrm{Y}$ \\
\hline Temperature $37^{\circ} \mathrm{C}$ & $\mathrm{Y}$ & $\mathrm{Y}$ & $\mathrm{Y}$ & $\mathrm{Y}$ & $\mathrm{Y}$ & $\mathrm{Y}$ & $\mathrm{Y}$ & $\mathrm{Y}$ & $\mathrm{Y}$ & $\mathrm{Y}$ & $\mathrm{Y}$ & $\mathrm{Y}$ & & $\mathrm{Y}$ \\
\hline Literature ref possibility & $\mathrm{Y}$ & $\mathrm{Y}$ & $\mathrm{N}$ & $\mathrm{N}$ & $\mathrm{Y}$ & $\mathrm{Y}$ & $\mathrm{Y}$ & $\mathrm{Y}$ & $\mathrm{N}$ & $\mathrm{Y}$ & $\mathrm{N}$ & $\mathrm{N}$ & & $\mathrm{Y}$ \\
\hline
\end{tabular}

Switzerland specifies primary literature, not review articles. Where this information is not available in the literature, human or in vitro data will be accepted as outlined below.

When not stated in the approved reference product labelling, the claim for complete drug absorption should be justified based on reliable investigation in humans for all participants, except for South Korea and the US, who also accept nonhuman systems capable of predicting the extent of absorption in humans. For all other participants, data from absolute oral bioavailability or massbalance studies should be provided to support the claim of high permeability. For human pharmacokinetic studies, information on study design and methods used along with the pharmacokinetic data should be provided. When assessing mass balance studies, the Biopharmaceutics Drug Disposition Classification System (BDDCS) criterion (i.e. oxidation and conjugation occur only after absorption) is used and is accepted by all the participants, except the US.

Data from animal Caco- 2 cells are accepted in South Korea and the US as primary evidence of the degree of permeability, but are accepted only as supporting data by Australia, Brazil, Colombia, Canada, EU, New Zealand, Singapore, South Africa, Switzerland, Taiwan and the WHO. It is critical that the suitability of the method is demonstrated when using in vitro permeability methods. The information provided should include 
a description of the study method, criteria for selection of human subjects, animals, or epithelial cell line, drug concentrations, description of the analytical method, method to calculate extent of absorption or permeability and information on the efflux potential (if appropriate). The method should determine the low and high permeability class boundaries using appropriate internal standards.

\section{In vitro dissolution of the drug product}

Having established high solubility and high or low permeability of the drug substance, the dissolution profiles of the test and reference products must demonstrate similarly rapid or very rapid dissolution in all conditions to be eligible for a BCS-based biowaiver. Dissolution parameters include, amongst others, the $\mathrm{pH}$ range, temperature range, number of dosage units, sample withdrawal time points, calculation of the similarity factor, dissolution methodology, apparatus specifications and rotation speed, surfactants, enzymes and validation of the dissolution methodology.

\section{Dissolution media pH and buffers}

All participants accept Ph.Eur. or USP buffers and require the dissolution profiles to be investigated in at least pH 1.2 (or simulated gastric fluid (SGF)), 4.5 and 6.8 (or simulated intestinal fluid (SIF)), except for South Korea, which currently requires $\mathrm{pH} 4.0$ but is however considering accepting $\mathrm{pH}$ 4.5. Specifically, for Australia, EU, New Zealand, Singapore, South Africa, Switzerland and the US, the dissolution media are $\mathrm{pH} 1.0$ to 1.2 (usually 0.1 $\mathrm{N} \mathrm{HCl}$ or SGF without enzymes), $\mathrm{pH} 4.5$, and $\mathrm{pH}$ 6.8 (or SIF without enzymes). Brazil, Canada, Colombia, Taiwan and the WHO recommend the use of Ph. Int. or alternative compendial buffers with the same $\mathrm{pH}$ and buffer capacity. Most participants, except Brazil, Colombia, Singapore, South Africa, Taiwan and the WHO, also require dissolution profiles at the $\mathrm{pH}$ of minimum solubility, if this differs from the specified $\mathrm{pHs}$. South Africa additionally requires the dissolution profiles in the final product dissolution specification medium if this is not one of the three specified dissolution media. The $\mathrm{pH}$ of the dissolution medium should be ensured throughout the experiment.

Table 3. Comparison of Drug Substance Absorption/Permeability Determination Requirements of IGDRP Participants (Y: Yes; N: No) ${ }^{\mathrm{a}}$

\begin{tabular}{|c|c|c|c|c|c|c|c|c|c|c|c|c|c|c|}
\hline $\begin{array}{l}\text { Drug Substance Absorption } \\
\text { / Permeability }\end{array}$ & 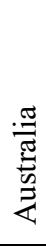 & ָี & 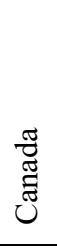 & $\frac{\pi}{0}$ & 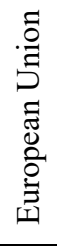 & 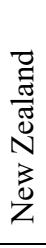 & 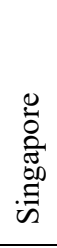 & 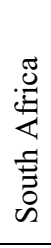 & 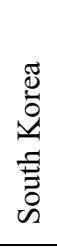 & 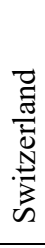 & 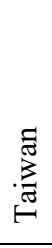 & $\mathscr{\Omega}$ & $\stackrel{0}{\stackrel{0}{1}}$ & \\
\hline \multicolumn{15}{|l|}{ High permeability } \\
\hline $85 \%$ & $\mathrm{Y}$ & $\mathrm{Y}$ & $\mathrm{Y}$ & Y & $\mathrm{Y}$ & $\mathrm{Y}$ & $\mathrm{Y}$ & Y & $\mathrm{N}^{\mathrm{b}}$ & $\mathrm{Y}$ & $\mathrm{Y}$ & $\mathrm{N}^{\mathrm{b}}$ & & Y \\
\hline $90 \%$ & $\mathrm{~N}$ & $\mathrm{~N}$ & $\mathrm{~N}$ & $\mathrm{~N}$ & $\mathrm{~N}$ & $\mathrm{~N}$ & $\mathrm{~N}$ & $\mathrm{~N}$ & $\mathrm{Y}$ & $\mathrm{N}$ & $\mathrm{N}$ & $\mathrm{Y}$ & & $\mathrm{N}$ \\
\hline $\begin{array}{l}\text { Acceptance of product } \\
\text { labelling }\end{array}$ & $\mathrm{Y}$ & $\mathrm{Y}$ & $\mathrm{Y}$ & $\mathrm{Y}$ & $\mathrm{Y}$ & $\mathrm{Y}$ & $\mathrm{Y}$ & $\mathrm{Y}$ & $\mathrm{Y}$ & $\mathrm{Y}$ & $\mathrm{Y}$ & $\mathrm{Y}$ & & $\mathrm{Y}$ \\
\hline $\begin{array}{l}\text { Acceptance of other literature } \\
\text { data as evidence of high } \\
\text { permeability }\end{array}$ & $\mathrm{Y}$ & $\mathrm{Y}$ & $\mathrm{Y}$ & $\mathrm{Y}$ & $\mathrm{Y}$ & $\mathrm{Y}$ & $\mathrm{Y}$ & $\mathrm{Y}$ & $\mathrm{Y}$ & $\mathrm{Y}$ & $\mathrm{Y}$ & $\mathrm{N}$ & & $\mathrm{Y}$ \\
\hline $\begin{array}{l}\text { Human data } \\
\text { absolute bioavailability or } \\
\text { mass balance using BDDCS } \\
\text { criterion }\end{array}$ & $\mathrm{Y}$ & $\mathrm{Y}$ & $\mathrm{Y}$ & $\mathrm{Y}$ & $\mathrm{Y}$ & $\mathrm{Y}$ & $\mathrm{Y}$ & $\mathrm{Y}$ & $\mathrm{Y}$ & $\mathrm{Y}$ & $\mathrm{Y}$ & $\mathrm{Y}$ & & $\mathrm{Y}$ \\
\hline Animal data accepted & $\mathrm{N}$ & $\mathrm{N}$ & $\mathrm{N}$ & $\mathrm{N}$ & $\mathrm{N}$ & $\mathrm{N}$ & $\mathrm{N}$ & $\mathrm{N}$ & $\mathrm{Y}$ & $\mathrm{N}$ & $\mathrm{N}$ & $\mathrm{Y}$ & & $\mathrm{N}$ \\
\hline Caco- 2 cell as primary data & $\mathrm{N}$ & $\mathrm{N}$ & $\mathrm{N}$ & $\mathrm{N}$ & $\mathrm{N}$ & $\mathrm{N}$ & $\mathrm{N}$ & $\mathrm{N}$ & Y & $\mathrm{N}$ & $\mathrm{N}$ & $\mathrm{Y}$ & & $\mathrm{N}$ \\
\hline $\begin{array}{l}\text { Caco-2 cell data supporting } \\
\text { only }\end{array}$ & $\mathrm{Y}$ & $\mathrm{Y}$ & Y & Y & $\mathrm{Y}$ & $\mathrm{Y}$ & $\mathrm{Y}$ & $\mathrm{Y}$ & $\mathrm{N}$ & $\mathrm{Y}$ & $\mathrm{Y}$ & $\mathrm{N}$ & & $\mathrm{Y}$ \\
\hline
\end{tabular}




\section{Surfactants and enzymes}

Surfactants are not accepted by any participant, as by definition the product must be rapidly or very rapidly dissolving without assistance.

Except for the US, which currently does not allow the use of enzymes under any circumstances, enzymes are allowed by all other participants for only gelatin capsules or tablets with a gelatin-based coating, as the cross-linking of gelatin may negatively affect the dissolution profiles, yet not be indicative of an in vivo failure. The US is however considering the allowance of enzymes for capsules and tablets with gelatin coating (20).

\section{Similarity factor $\left(f_{2}\right)$}

All participants use the similarity factor $f_{2}$ to determine similarity of dissolution profiles of the relevant formulations. Requirements for the calculation of the similarity factor $f_{2}$ relate to the acceptable variability at each sampling time point and the sampling time points used in the calculation.

When the variability of the individual dosage units at each sampling time is higher than acceptable for $f_{2}$ calculations, all participants except Brazil either do a case by case assessment or may accept alternative models, e.g. the $90 \%$ confidence interval of the $f_{2}$ similarity factor (2224) or the Mahalanobis distance or multivariate statistical distance based on model independent or model dependent approaches (25-27).

All participants limit the sampling time points to be included in the calculation of the $f_{2}$ similarity factor between the test and reference products as follows:

- $\quad$ Points up to the sampling time where one of the formulations has dissolved $85 \%$ or more are used by Australia, EU, New Zealand, Singapore and Switzerland.

- $\quad$ Points up to the sampling time where both test and reference have reached $85 \%$ or more are used by Brazil, Canada, South Korea, South Africa, Taiwan and the US.

- Points up to the sampling time where the reference product has reached $85 \%$ or more are used by Colombia and the WHO.

\section{Dissolution test methodology}

Differences exist amongst the participants regarding the number of batches to be tested and the rotation speed of the basket or paddle.

Brazil, Colombia, South Korea, Singapore, South Africa, Taiwan, the US and the WHO accept comparison of one batch of both the test and reference products; South Africa recommends more than one batch, if possible, and the WHO Prequalification Programme requires two batches of the reference product (28). Australia, EU, New Zealand and Switzerland recommend comparison of at least two batches of the reference and test products. Canada recommends comparison of at least two batches of the test product with one batch of the reference product.

When using the paddle apparatus, the rotation speed should be $50 \mathrm{rpm}$, with some participants (Colombia, South Africa, Taiwan and the WHO) allowing a faster paddle speed of up to $75 \mathrm{rpm}$ to reduce coning. Canada could accept $75 \mathrm{rpm}$ if coning affects both test and reference products. The rotation speed of the basket is typically $100 \mathrm{rpm}$.

All participants agree on most other aspects of dissolution testing requirements or have only slight differences.

All participants agree on the definitions for rapid and very rapid dissolution, i.e. $\geq 85 \%$ in 30 minutes, and $\geq 85 \%$ in 15 minutes, respectively. All participants require similarly rapid and complete dissolution for the test and the reference for BCS Class I biowaivers. Those participants that would consider a BCS Class III biowaiver require a very rapid dissolution profile for both the test and reference products.

Compendial dissolution methodology, apparatus and standards of the $\mathrm{Ph}$. Eur., $\mathrm{Ph}$. Int. or USP are required by all participants. Generally, all participants require validation of the dissolution methodology, as well as validation of the analytical method. All participants require testing of at least 12 units of each product batch in each dissolution medium, either the paddle or basket apparatus, and a volume of $900 \mathrm{~mL}$ or less.

There are only slight differences among the participants regarding sampling time points, water bath temperatures and dissolution study documentation. The recommended sampling time points are 10,15, 20, 30 and 45 minutes for all participants with the exception of Canada, Colombia, Taiwan and the WHO who recommend an additional sampling time point of 5 minutes. South Korea, Mexico, the US and the WHO require the bath temperature $37 \pm 0.5^{\circ} \mathrm{C}$, while the remainder allow $37 \pm 1^{\circ} \mathrm{C}$. Lastly, while a complete dissolution report is mandatory for all participants and a study protocol is generally necessary, the latter is not specified by Colombia, South Africa and the WHO (but is required in the WHO Prequalification Programme), is preferable 
for Singapore and is not required for South Korea and Taiwan.

\section{Excipients}

The excipients of the test and reference product formulations must be evaluated to affirm the applicability of a BCS-based biowaiver (3). Excipients that might affect the bioavailability of the drug substance e.g., mannitol, sorbitol, or surfactants, should be identified (5).
All participants could consider BCS Class I biowaivers for formulations with excipients different to those of the reference product, if they are within ranges normally used in the dosage form. Those excipients that might affect bioavailability should be qualitatively the same and quantitatively very similar or the same for most participants. In South Korea and the US, only large amounts of these excipients or large differences are considered to be clinically relevant.

Table 4. Comparison of Dissolution requirements of IGDRP Participants (Y: Yes; N: No)

\begin{tabular}{|c|c|c|c|c|c|c|c|c|c|c|c|c|c|c|}
\hline Product dissolution & 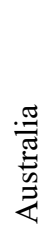 & : & 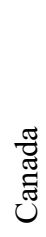 & $\begin{array}{l}\frac{\pi}{0} \\
\frac{0}{0} \\
0 \\
0\end{array}$ & 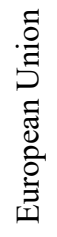 & 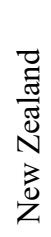 & 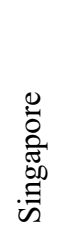 & 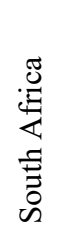 & 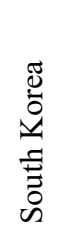 & 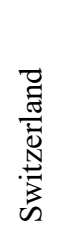 & 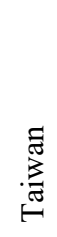 & $\underset{\mathscr{D}}{\mathscr{\varpi}}$ & $\stackrel{0}{3}$ & \\
\hline \multicolumn{15}{|l|}{$\mathrm{pH}$} \\
\hline at least $1.2,4.5,6.8$ & $\mathrm{Y}$ & $\mathrm{Y}$ & $\mathrm{Y}$ & $\mathrm{Y}$ & $\mathrm{Y}$ & $\mathrm{Y}$ & $\mathrm{Y}$ & $\mathrm{Y}$ & $\mathrm{Y}$ & $\mathrm{Y}$ & $\mathrm{Y}$ & $\mathrm{Y}$ & & $\mathrm{Y}$ \\
\hline $\mathrm{pH}$ minimum solubility & $\mathrm{Y}$ & $\mathrm{N}$ & $\mathrm{Y}$ & $\mathrm{N}$ & $\mathrm{Y}$ & $\mathrm{Y}$ & $\mathrm{N}$ & $\mathrm{N}$ & $\mathrm{N}$ & $\mathrm{Y}$ & $\mathrm{N}$ & $\mathrm{N}$ & & $\mathrm{N}$ \\
\hline Plus QC medium & $\mathrm{N}$ & $\mathrm{N}$ & $\mathrm{N}$ & $\mathrm{N}$ & $\mathrm{N}$ & $\mathrm{N}$ & $\mathrm{N}$ & $\mathrm{Y}$ & $\mathrm{N}$ & $\mathrm{N}$ & $\mathrm{N}$ & $\mathrm{N}$ & & $\mathrm{N}$ \\
\hline Volume $900 \mathrm{~mL}$ or less & $\mathrm{Y}$ & $\mathrm{Y}$ & $\mathrm{Y}$ & $\mathrm{Y}$ & $\mathrm{Y}$ & $\mathrm{Y}$ & $\mathrm{Y}$ & $\mathrm{Y}$ & $\mathrm{Y}$ & $\mathrm{Y}$ & $\mathrm{Y}$ & $\mathrm{Y}$ & & $\mathrm{Y}$ \\
\hline pH range 1 to 7.5 & $\mathrm{~N}$ & $\mathrm{~N}$ & $\mathrm{~N}$ & $\mathrm{~N}$ & $\mathrm{~N}$ & $\mathrm{~N}$ & $\mathrm{~N}$ & $\mathrm{~N}$ & $\mathrm{~N}$ & $\mathrm{~N}$ & $\mathrm{~N}$ & $\mathrm{Y}$ & & $\mathrm{N}$ \\
\hline pH range 1 to 6.8 & $\mathrm{Y}$ & $\mathrm{N}$ & $\mathrm{N}$ & $\mathrm{N}$ & $\mathrm{Y}$ & $\mathrm{Y}$ & $\mathrm{Y}$ & $\mathrm{N}$ & $\mathrm{N}$ & $\mathrm{Y}$ & $\mathrm{Y}$ & $\mathrm{N}^{\mathrm{b}}$ & & $\mathrm{N}$ \\
\hline $\mathrm{pH}$ range 1.2 to 6.8 & $\mathrm{~N}$ & $\mathrm{Y}$ & $\mathrm{Y}$ & $\mathrm{Y}$ & $\mathrm{N}$ & $\mathrm{N}$ & $\mathrm{N}$ & $\mathrm{Y}$ & $\mathrm{Y}$ & $\mathrm{N}$ & $\mathrm{N}$ & $\mathrm{N}$ & & $\mathrm{Y}$ \\
\hline Surfactants accepted & $\mathrm{N}$ & $\mathrm{N}$ & $\mathrm{N}$ & $\mathrm{N}$ & $\mathrm{N}$ & $\mathrm{N}$ & $\mathrm{N}$ & $\mathrm{N}$ & $\mathrm{N}$ & $\mathrm{N}$ & $\mathrm{N}$ & $\mathrm{N}$ & & $\mathrm{N}$ \\
\hline $\begin{array}{l}\text { Enzymes accepted for gelatin } \\
\text { capsules or tablets with gelatin } \\
\text { coating }\end{array}$ & $\mathrm{Y}$ & $\mathrm{Y}$ & $\mathrm{Y}$ & $\mathrm{Y}$ & $\mathrm{Y}$ & $\mathrm{Y}$ & $\mathrm{Y}$ & $\mathrm{Y}$ & $\mathrm{Y}$ & $\mathrm{Y}$ & $\mathrm{Y}$ & $\mathrm{N}^{\mathrm{b}}$ & & $\mathrm{Y}$ \\
\hline Similarity factor $f_{2}$ & $\mathrm{Y}$ & $\mathrm{Y}$ & $\mathrm{Y}$ & $\mathrm{Y}$ & $\mathrm{Y}$ & $\mathrm{Y}$ & $\mathrm{Y}$ & $\mathrm{Y}$ & $\mathrm{Y}$ & $\mathrm{Y}$ & $\mathrm{Y}$ & $\mathrm{Y}$ & & $\mathrm{Y}$ \\
\hline Alternative models to $f_{2}$ & $\mathrm{Y}$ & $\mathrm{N}$ & $\mathrm{Y}$ & Y & Y & $\mathrm{Y}$ & Y & Y & Y & Y & Y & $\mathrm{Y}$ & & Y \\
\hline \multicolumn{15}{|c|}{ Sampling time points used in calculation of $f_{2}$ : } \\
\hline $\begin{array}{l}\text { Up to one point after } 85 \% \\
\text { dissolved }\end{array}$ & $\mathrm{Y}$ & $\mathrm{Y}$ & $\mathrm{Y}$ & $\mathrm{Y}$ & $\mathrm{Y}$ & $\mathrm{Y}$ & $\mathrm{Y}$ & $\mathrm{Y}$ & $\mathrm{N}$ & $\mathrm{Y}$ & $\mathrm{Y}$ & $\mathrm{N}$ & & $\mathrm{Y}$ \\
\hline -One formulation & $\mathrm{Y}$ & $\mathrm{N}$ & $\mathrm{N}$ & $\mathrm{N}$ & $\mathrm{Y}$ & $\mathrm{Y}$ & $\mathrm{Y}$ & $\mathrm{N}$ & $\mathrm{N}$ & $\mathrm{Y}$ & $\mathrm{N}$ & $\mathrm{N}$ & & $\mathrm{N}$ \\
\hline -Both test and reference & $\mathrm{N}$ & $\mathrm{Y}$ & $\mathrm{Y}$ & $\mathrm{N}$ & $\mathrm{N}$ & $\mathrm{N}$ & $\mathrm{N}$ & $\mathrm{Y}$ & $\mathrm{Y}$ & $\mathrm{N}$ & $\mathrm{Y}$ & $\mathrm{Y}$ & & $\mathrm{N}$ \\
\hline -Reference & $\mathrm{N}$ & $\mathrm{N}$ & $\mathrm{N}$ & $\mathrm{Y}$ & $\mathrm{N}$ & $\mathrm{N}$ & $\mathrm{N}$ & $\mathrm{N}$ & $\mathrm{N}$ & $\mathrm{N}$ & $\mathrm{N}$ & $\mathrm{N}$ & & $\mathrm{Y}$ \\
\hline \multicolumn{15}{|l|}{ Temperature } \\
\hline $37 \pm 0.5^{\circ} \mathrm{C}$ & $\mathrm{N}$ & $\mathrm{N}$ & $\mathrm{N}$ & $\mathrm{N}$ & $\mathrm{N}$ & $\mathrm{N}$ & $\mathrm{N}$ & $\mathrm{N}$ & $\mathrm{Y}$ & $\mathrm{N}$ & $\mathrm{N}$ & $\mathrm{Y}$ & & Y \\
\hline $37 \pm 1^{\circ} \mathrm{C}$ & $\mathrm{Y}$ & $\mathrm{Y}$ & $\mathrm{Y}$ & $\mathrm{Y}$ & $\mathrm{Y}$ & $\mathrm{Y}$ & $\mathrm{Y}$ & $\mathrm{Y}$ & $\mathrm{N}$ & $\mathrm{Y}$ & $\mathrm{Y}$ & $\mathrm{N}$ & & $\mathrm{N}$ \\
\hline Paddle $50 \mathrm{rpm}$ & $\mathrm{Y}$ & $\mathrm{Y}$ & $\mathrm{Y}$ & $\mathrm{Y}$ & $\mathrm{Y}$ & $\mathrm{Y}$ & $\mathrm{Y}$ & $\mathrm{Y}$ & $\mathrm{Y}$ & $\mathrm{Y}$ & $\mathrm{Y}$ & $\mathrm{Y}$ & & $\mathrm{Y}$ \\
\hline Paddle $75 \mathrm{rpm}$ & $\mathrm{N}$ & $\mathrm{N}$ & $\mathrm{N}$ & $\mathrm{Y}$ & $\mathrm{N}$ & $\mathrm{N}$ & $\mathrm{N}$ & $\mathrm{Y}$ & $\mathrm{N}$ & $\mathrm{N}$ & $\mathrm{Y}$ & $\mathrm{N}$ & & $\mathrm{Y}$ \\
\hline Basket 100 rpm & $\mathrm{Y}$ & $\mathrm{Y}$ & $\mathrm{Y}$ & $\mathrm{Y}$ & $\mathrm{Y}$ & $\mathrm{Y}$ & $\mathrm{Y}$ & $\mathrm{Y}$ & $\mathrm{Y}$ & $\mathrm{Y}$ & $\mathrm{Y}$ & $\mathrm{Y}$ & & $\mathrm{Y}$ \\
\hline $\begin{array}{l}\text { Time points } 10,15,20,30,45 \\
\text { minutes }\end{array}$ & $\mathrm{Y}$ & $\mathrm{Y}$ & $\mathrm{N}$ & $\mathrm{N}$ & $\mathrm{Y}$ & $\mathrm{Y}$ & $\mathrm{Y}$ & $\mathrm{Y}$ & $\mathrm{Y}$ & $\mathrm{Y}$ & $\mathrm{Y}$ & $\mathrm{Y}$ & & $\mathrm{N}$ \\
\hline $\begin{array}{l}\text { Time points } 5,10,15,20,30,45 \\
\text { minutes }\end{array}$ & $\mathrm{N}$ & $\mathrm{N}$ & $\mathrm{Y}$ & $\mathrm{N}$ & $\mathrm{N}$ & $\mathrm{N}$ & $\mathrm{N}$ & $\mathrm{N}$ & $\mathrm{N}$ & $\mathrm{N}$ & $\mathrm{Y}$ & $\mathrm{N}^{\mathrm{b}}$ & & $\mathrm{Y}$ \\
\hline $\begin{array}{l}\text { Time points } 5,10,15,20,30,45 \text {, } \\
60 \text { minutes }\end{array}$ & $\mathrm{N}$ & $\mathrm{N}$ & $\mathrm{N}$ & $\mathrm{Y}$ & $\mathrm{N}$ & $\mathrm{N}$ & $\mathrm{N}$ & $\mathrm{N}$ & $\mathrm{N}$ & $\mathrm{N}$ & $\mathrm{N}$ & $\mathrm{N}$ & & $\mathrm{N}$ \\
\hline
\end{tabular}


For Canada, these excipients should not differ from the reference product by more than $10 \%$. For Colombia and the WHO, these excipients should not differ by more than SUPAC-IR Level 1 with respect to the reference product, but the WHO Prequalification Programme requires that the quantities of these critical excipients should be the same (28).

All participants that consider BCS Class III biowaivers require the formulations to be qualitatively identical (except for the coating, colours and flavours), with all the excipients being quantitatively very similar/similar and those excipients that may affect bioavailability being quantitatively the same, with the exception of the WHO that requires quantitative similarity as for BCS Class I drugs.

\section{Fixed dose combinations}

Australia, Canada, Colombia, EU, South Korea, New Zealand, Singapore, South Africa, Switzerland, Taiwan and the WHO would consider fixed dose combination biowaivers if all the drug substances are BCS class I or III. The US is considering accepting BCS-based biowaivers for fixed dose combinations (20). If a biowaiver is not appropriate for one of the drug substances, an in vivo study is necessary and all drug substances should be measured. Brazil and Canada accept a BCS-based biowaiver for one of the component drugs provided there is no interaction between the drug substances.

\section{DISCUSSION}

The BCS classification system is an objective, science-based approach with the purpose of identifying possible biowaivers to avoid unnecessary in vivo bioequivalence studies. This review reveals that two participants do not currently accept BCS-based biowaivers and that there are differences in the interpretation and implementation of these biowaivers for those that do accept them. However, there are also many similarities in the requirements of the participants.

The most important difference that hinders harmonisation of BCS-based biowaiver requirements relates to whether solubility is classified using the highest strength or the highest single therapeutic dose of the reference product. Other complicating factors include differences in whether in vitro permeability data can be accepted to support a permeability classification and the necessity of conducting comparative dissolution testing between the test product and the local reference product in each jurisdiction.

The survey identified several areas for potential regulatory harmonisation or convergence. The greatest similarities in the approach to BCS-based biowaivers were observed between Australia, Canada, Colombia, EU, New Zealand, South Africa, Switzerland, Taiwan and the WHO because of the use of a similar $\mathrm{pH}$ range for the solubility classification, similar requirements for permeability data and the same cut-off point for the permeability classification at $85 \%$. Except for Taiwan, all of these participants base the solubility classification on the highest single dose stated in the reference product labelling. Furthermore, these participants all accept BCS Class III biowaivers. Harmonisation with Singapore is possible because of the same cut-off value for permeability classification $(85 \%)$ and $\mathrm{pH}$ range for solubility classification (1.0 to 6.8). Singapore currently accepts only BCS Class I biowaivers and is reviewing its position on $\mathrm{BCS}$ Class III biowaivers. In contrast, harmonization with Brazil will be more challenging because the acceptability of BCS-based biowaivers is limited to those BCS class I drug substances listed in their regulations. similar challenges exist for South Korea and the US, based on a different cut-off value for the permeability classification $(90 \%)$ and the wider $\mathrm{pH}$ range (1.0 to 7.5 ) for the solubility classification. Additionally, the US requires experimental data for the permeability classification, unless the absolute bioavailability is stated in the labelling of the reference product. However, they continue to make strides towards harmonisation. This is evident by the recently revised draft BCS guidance document published by the US in 2015 (20), as detailed above.

\section{CONCLUSIONS}

This review has, with the exception of two participants who do not accept BCS-based biowaivers, revealed that the remainder accept them with varying requirements. Most IGDRP participants interpret the BCS principles and conditions similarly and in many instances agree on specific requirements. This review identifies potential areas for further regulatory convergence in considerable detail. Importantly, and signifying the relevance of this profound scientific and regulatory discussion internationally, BCS-based biowaivers is currently under review by the International Council for Harmonisation of 
Technical Requirements for Pharmaceuticals for Human Use (ICH) as a topic for potential harmonisation (29) of this approach to avoiding unnecessary in vivo studies while also ensuring the quality, safety and efficacy of medicines, especially generics.

\section{DECLARATION}

This manuscript represents the personal opinion of the authors and does not necessarily represent the views or policy of their corresponding regulatory agencies.

\section{REFERENCES}

1. International Generic Drug Regulators Programme (IGDRP) [Internet]. Available from: www.igdrp.com

2. Amidon GL, Lennernas H, Shah VP, Crison JR. A theoretical basis for a biopharmaceutic drug classification: the correlation of in vitro drug product dissolution and in vivo bioavailability. Pharm Res. United States; 1995 Mar;12(3):413-20.

3. Polli JE, Abrahamsson BSI, Yu LX, Amidon GL, Baldoni JM, Cook JA, et al. Summary workshop report: bioequivalence, biopharmaceutics classification system, and beyond. AAPS J. United States; 2008 Jun;10(2):373-9.

4. Davit B, Braddy AC, Conner DP, Yu LX. International guidelines for bioequivalence of systemically available orally administered generic drug products: a survey of similarities and differences. AAPS J. United States; 2013 Oct;15(4):974-90.

5. Committee for Medicinal Products for Human Use (CHMP) European Medicines Agency (EMA). Guideline on the Investigation of Bioequivalence CPMP/EWP/QWP/1401/98 Rev. 1/Corr [Internet]. 2010. Available from: http://www.ema.europa.eu/docs/en_GB/docum ent_library/Scientific_guideline/2010/01/WC5 00070039.pdf

6. Health Canada. Guidance Document: Biopharmaceutics Classification System Based Biowaiver [Internet]. 2014. Available from: https://www.canada.ca/content/dam/hcsc/migration/hc-sc/dhpmps/alt_formats/pdf/prodpharma/applicdemande/guide-ld/bcs_guide_ld_scb-eng.pdf

7. WHO Expert Committe on Specifications for Pharmaceutical Preparations. Annex 7 Multisource (generic) Pharmaceutical Products: Guidelines on Registration Requirements to Establish Interchangeability [Internet]. WHO Technical Report Series, No.
992. 2006. Available from: http://www.who.int/medicines/areas/quality s afety/quality_assurance/Annex7-TRS992.pdf

8. US Department of Health and Human Services Food and Drug Administration Center for Drug Evaluation and Research. Guidance for Industry: Waiver of In Vivo Bioavailability and Bioequivalence Studies for Immediate-Release Solid Oral Dosage Forms Based on a Biopharmaceutics Classification System. 2000.

9. Ministry of Food and Drug Safety (South Korea). Standard on Pharmaceutical Equivalence Study; Notification No. 2017-28 (Apr. 19, 2017, Amended)]. 2017.

10. Brazilian Health Regulatory Agency (ANVISA). Resolution RDC no 37, 3 August 2011. Provides information about biowaiver and substitution of bioequivalence studies. [Internet]. 2011. Available from: http://portal.anvisa.gov.br/documents/33880/2 568070/rdc0037 0308 2011.pdf/13c41657e93b-4d09-99eb-377f760f3aa0

11. Health Sciences Authority (Singapore). Guidance on Therapeutic Product Registration in Singapore. Appendix 10 Product Interchangeability and Biowaiver Request for Chemical Generic Drug Applications [Internet]. Singapore; 2016. Available from: http://www.hsa.gov.sg/content/dam/HSA/HPR G/Western_Medicine/Overview_Framework Policies/Guidelines_on_Drug_Registration/DR_Guide_2016/DR $\% 20$ guide $\% 202016 \% 20$ fin al/Appendix\%2010_Product\%20Interchangea bility\%20and\%20Biowaiver\%20Request $\% 20$ f or\%20Chemical\%20Generic\%20Drug\%20Ap plications_30Nov16.pdf

12. Therapeutic Goods Administration (Australia). Guidance 15: Biopharmaceutic studies, Australian Regulatory Guidelines for Prescription Medicines (ARGPM) [Internet]. 2015. Available from: https://www.tga.gov.au/guidance-15biopharmaceutic-studies

13. Medicines Control Council (South Africa). Dissolution [Internet]. 2015. Available from: http://www.mccza.com/documents/0ca3cfe72. 07 Dissolution Jun15 v5.pdf

14. Medicines Control Council (South Africa). Pharmaceutical and Analytical CTD /eCTD [Internet]. 2014. Available from: http://www.mccza.com/documents/751d10ba2 .25_PA_CTD_Aug14_v4.pdf

15. Médicines Control Council (South Africa). Biostudies [Internet]. 2015. Available from: http://www.mccza.com/documents/61de452d2 .06_Biostudies_Jun15_v6.pdf

16. Instituto Nacional de Vigilancia de Medicamentos y Alimentos (Colombia). Resolución número 1124 de 2016. Ministerio de Salud y Seguridad Social. República de 
Colombia. Anexo Técnico 1. Guía de biodisponibilidad y bioequivalencia de productos farmacéuticos. [Internet]. 2016. Available from: https://www.invima.gov.co/images/bioequival encia/Resolución 1124 de 2016.pdf

17. Taiwan Food and Drug Administration (Taiwan). Guideline for Biopharmaceutics Classification System (BCS)-Based Biowaiver Applications of Generic Drugs (Chinese version only). [Internet]. 2005. Available from: http://mohwlaw.mohw.gov.tw/FLAW/FLAW DAT0202. aspx?1sid=FL081775

18. Taiwan Food and Drug Administration (Taiwan). Regulation of Bioavailability and Bioequivalence Studies (English version). [Internet]. 2006. Available from: http://mohwlaw.mohw.gov.tw/ENG/EngConte nt.aspx?msgid $=628$

19. Medsafe (New Zealand). Guideline on the Regulation of Therapeutic Products in New Zealand. Part 6: Bioequivalence of medicines [Internet]. 2015. Available from: http://www.medsafe.govt.nz/regulatory/Guidel ine/GRTPNZ/bioequivalence-of-medicines.pdf

20. US Department of Health and Human Services Food and Drug Administration Center for Drug Evaluation and Research. Guidance for Industry: Waiver of In Vivo Bioavailability and Bioequivalence Studies for Immediate-Release Solid Oral Dosage Forms Based on a Biopharmaceutics Classification System (Draft) [Internet]. 2015. Available from: https:/www.fda.gov/downloads/Drugs/Guidan ceComplianceRegulatoryInformation/Guidanc es/UCM070246.pdf

21. US Department of Health and Human Services Food and Drug Administration Center for Drug Evaluation and Research. Guidance on Linezolid [Internet]. 2011. Available from: https://www.fda.gov/downloads/Drugs/Guidan ceComplianceRegulatoryInformation/Guidanc es/ucm118264.pdf

22. Shah, VP, Tsong Y, Sathe P, Liu JP. In vitro dissolution profile comparison- Statistics and analysis of the similarity factor, f2. Pharm Res. 1998; 15(6):8889-96.

23. Mangas-Sanjuan V, Colon-Useche S, Gonzalez-Alvarez I, Bermejo M, Garcia-Arieta A. Assessment of the Regulatory Methods for the Comparison of Highly Variable Dissolution Profiles. AAPS J. United States; 2016 Nov;18(6):1550-61.

24. Paixao P, Gouveia LF, Silva N, Morais JAG. Evaluation of dissolution profile similarity Comparison between the $\mathrm{f} 2$, the multivariate statistical distance and the $\mathrm{f} 2$ bootstrapping methods. Eur J Pharm Biopharm. Netherlands; 2017 Mar;112:67-74.

25. Sathe PM, Tsong U, Shah VP. In vitro dissolution profile comparison: Statistics and analsis, model dependent approach. Pharm Res. 1996;13(12):1799-803.

26. Tsong Y, Hammerstrom T, Sathe P, Shah VP. Statistical assessment of mean differences between two dissolution data sets. Drug Inf J. 1996;30(4):1105-12.

27. US Department of Health and Human Services Food and Drug Administration Center for Drug Evaluation and Research. Guidance for Industry Dissolution Testing of Immediate Release Solid Oral Dosage Forms [Internet]. 1997. Available from: https://www.fda.gov/downloads/drugs/guidanc es/ucm070237.pdf

28. WHO Prequalification Team - Medicines. General Notes on Biopharmaceutics Classification System (BCS)-Based Biowaiver Applications [Internet]. 2014. Available from: http://apps.who.int/medicinedocs/documents/s 21674en/s21674en.pdf

29. International Council for Harmonisation of Technical Requirements (ICH). Final Endorsed Concept Paper - M9 Biopharmaceutics Classification System-based Biowaivers [Internet]. 2016. Available from: http://www.ich.org/products/guidelines/multid isciplinary/article/multidisciplinaryguidelines.html 